\title{
MORPHOLOGICAL CHARACTERISTICS OF LEAF OF DIFFERENT DEVELOPMENT STAGES OF LATE SUCCESSIONAL CANOPY TREE SPECIES IN A SRI - LANKAN LOWLAND RAIN FOREST
}

\author{
P A K A K Panditharathna and B M P Singhakumara \\ Department of Forestry and Environmental Science, \\ University of Sri Jayewardenepura, Nugegoda.
}

This study examined the morphological characteristics of four development stages of four canopy species belong to two families that have been characterized as late successional. Variations in leaf morphological characters were studied among seedlings $(50 \mathrm{~cm}$ in height), saplings ( $2-5.5 \mathrm{~m}$ height), pole size $(15-20 \mathrm{~m}$ height) and mature trees $(>25 \mathrm{~m}$ height). Two species belong to family Clusiaceae (Mesua ferrea, Mesua nagassarium) and two species belong to the family Dipterocarpaceae (Shorea worthingtonii, Shorea megistophylla). Sample leaves were collected from Sinharaja, a forest located in the southwest lowland wet zone of Sri Lanka. Morphological characters measured were leaf area, leaf length, leaf width and length of drip tip. To study these characters ten individuals were taken for each development stage of a species. Three leaves were sampled from an individual and leaf length, leaf area, leaf width and length of drip tip were measured for each leaf.

Data were analysed using a one way ANOVA and Tukey's studentised range to determine differences among development stages at 5\% significance level. Results indicate that saplings of all species had the highest leaf area, leaf length and leaf width. Seedlings had the highest length of drip tip.

This study revealed that there are morphological variations within a species of late successional canopy tree species.

Proceedings of the Third Annual Forestry Symposium 1997, of the Department of Forestry and Environmental Science, University of Sri Jayewardenepura, Sri Lanka 